\title{
Tanggung Jawab Hukum Atas Pasien Gangguan Jiwa Yang Melarikan Diri Dari Ruang Rawat Inap Rumah Sakit
}

\author{
Mulyono, Dewi Setyowati, Kamarudin \\ Fakultas Hukum, Universitas Hang Tuah, Surabaya \\ E-mail: mulyonorm@gmail.com
}

\begin{abstract}
:
Health jurisdiction at this time is increasingly widespread, people are becoming increasingly aware of their rights protected by law. Juridically the hospital is responsible for all losses caused by negligence of health workers in the hospital. To minimize or eliminate losses due to negligence of medical personnel, hospitals hire employees in accordance with his profession to give direct patient health. In the background there is a legal issue in hospital services, namely legal responsibility for mentally ill patients who have escaped from the inpatient hospital. There will be legality problems and the burden of responsibility to the hospital or guard officer in the inpatient room for mental patients who escape from the hospital inpatient room. The research method used in the research is descriptive normative, using a statute approach and conceptual approach. Legal materials used are a source of primary law (criminal code, civil code, the law of the health sector, and regulations the minister of health) and secondary legal materials (textbooks, literature, the literature related to the discussion). Results of the research showed that responsibility for mental patients who escaped from the room inpatient can be grouped into three groups, namely responsible for the field of hospital, the person in charge is the head of the hospital, responsible for the medical field, the person in charge is each doctor, responsibility of the nursing field, the person in charge is each nurse. Where this is a civil case then becomes the responsibility of the home, and when the criminal case it becomes important responsibility beach offender.
\end{abstract}

Keywords: responsibility, hospital, patient

\begin{abstract}
Abstrak:
Yuridiksi kesehatan pada saat ini kian marak, masyarakat menjadi semakin sadar akan hak-haknya yang dilindungi oleh hukum. Secara yuridis rumah sakit bertanggungjawab atas semua kerugian yang diakibatkan oleh kelalaian tenaga kesehatan di rumah sakit. Untuk meminimalisir bahkan meniadakan kerugian akibat kelalaian tenaga kesehatan, rumah sakit mempekerjakan karyawan sesuai dengan profesi nya untuk memberikan pelayanan kesehatan pasien secara langsung. Dalam latar belakang terdapat isu hukum dalam pelayanan di rumah sakit, yaitu tanggungjawab hukum atas pasien gangguan jiwa yang melarikan diri dari ruang rawat inap rumah sakit. Maka timbul permasalahan legalitas dan pembebanan tanggungjawab kepada rumah sakit atau petugas jaga di ruang rawat inap terhadap pasien gangguan jiwa yang melarikan diri dari ruang rawat inap rumah sakit. Metode penelitian yang digunakan dalam penelitian adalah deskriptif normatif, dengan menggunakan pendekatan undang-undang (statute approach) dan pendekatan konseptual(conceptual approach). Bahan hukum yang digunakan adalah sumber bahan hukum primer yakni peraturan perundang-undangan(KUHP, KUHPerdata, Undang-undang bidang kesehatan, dan peraturan menteri kesehatan) dan bahan hukum sekunder (buku teks, kepustakaan, literatur yang terkait dengan pembahasan). Hasil dari penelitian didapatkan bahwa tanggungjawab atas pasien gangguan jiwa yang melarikan
\end{abstract}


diri dari ruang rawat inap rumah sakit dapat dikelompokkan menjadi tiga golongan yaitu tanggung jawab bidang perumahsakitan, penanggung jawab adalah kepala rumah sakit, tanggung jawab bidang medik, penanggung jawab adalah masing-masing dokter, tanggung jawab bidang keperawatan, penanggung jawab adalah masing-masing perawat. Bilamana hal ini adalah kasus perdata maka menjadi tanggung jawab rumah, dan bila kasusnya pidana maka menjadi tanggungjawab masing-masing pelaku.

Kata kunci : tanggung jawab, rumah sakit, pasien

\section{Pendahuluan}

Fenomena sengketa medik di rumah sakit semakin kompleks, terlebih terjadi di Rumah Sakit Khusus, dalam hal ini Rumah Sakit Jiwa (RSJ). Oleh sebab itu, Kementerian Kesehatan mengalokasikan anggaran khusus untuk pelatihan keperawatan jiwa bagi paramedis di berbagai institusi pelayanan kesehatan. ${ }^{1}$ Perhatian terhadap pasien/orang dengan gangguan jiwa, dalam sejarah peraturan perundangan di Indonesia, telah diatur tersendiri dalam Undang-Undang Republik Indonesia Nomor 18 Tahun 2014 Tentang Kesehatan Jiwa (yang menggantikan Undang-Undang Nomor 3 tahun 1996 tentang Kesehatan Jiwa). Keberadaan Rumah Sakit jiwa tergolong sebagai Rumah Sakit Khusus. Klasifikasi Rumah Sakit Khusus ini lebih jelas dituangkan Peraturan Menteri Kesehatan Nomor 340/MENKES/PER/III/2010 Tentang Klasifikasi Rumah Sakit.

Karakteristik yang khusus pelayanan kesehatan yang diberikan oleh Rumah Sakit Jiwa, terletak pada pelayanan bagi pasien/orang gangguan jiwa. Sengketa medik yang sering terjadi antara pihak keluarga pasien/orang yang menderita gangguan jiwa dengan rumah sakit termasuk dirumah sakit jiwa disebabkan karena suatu kelalaian yang dilakukan oleh tenaga kesehatan yang mempunyai dampak secara kelembagaan pada pihak Rumah Sakit. ${ }^{2}$

Dalam Undang Undang Nomor 36 tahun 2009 tentang Kesehatan, telah mengatur hal-hal yang berkaitan dengan masalah kelalaian tenaga kesehatan, misalnya pada Pasal 29 dan Pasal 58. Pasal 29 menyebutkan bahwa dalam hal tenaga kesehatan

${ }^{1}$ Lihat dalam Indonesia.ucanews.com. Berita tanggal 17/12/2012. Buruknya Pelayanan Terhadap Orang Gangguan Jiwa, Pemerintah Alokasikan Anggaran., diakses pada http://indonesia.ucanews.com/buruknya-pelayanan-terhadap-orang-gangguan-jiwapemerintahalokasikan-anggaran. Lihat juga di bintangpapua.com. Berita pada hari sabtu, 8 Juli 2017 08:15 Ada Malpraktek di RSUD Dok 11 Jayapura? Dari Demo Ormas dan LSM ke DPRP. Seorang Pasien Gangguan Jiwa Bernama Udin Tewas Setelah Disuntik Berkali-kali di RSUD Dok II Jayapura, Maret Silam., http://bintangpapua.com/index.php/2012-12-03-03-14-02/2013-01-02-06-1235/item/5968-ada-malpraktek-di-rsud-dok-ii-jayapura, diakses tanggal 23 Desember 2017.

2 Basuni, B. (2014). Tanggung Jawab Rumah Sakit Jiwa Terhadap Pegawai Yang Melakukan Kesalahan Tindakan Dalam Perawatan Pasien Gangguan Jiwa (Studi di Rumah Sakit Jiwa Menur Surabaya). Perspektif Hukum, 14 14(2), doi:http://dx.doi.org/10.30649/phj.v14i2.36 
diduga melakukan kelalaian dalam menjalankan profesinya, kelalaian tersebut harus diselesaikan terlebih dahulu melalui mediasi. Pasal 58 mengatur mengenai hak setiap orang untuk menuntut ganti rugi terhadap seseorang, tenaga kesehatan, dan/atau penyelenggara kesehatan yang menimbulkan kerugian akibat kesalahan atau kelalaian dalam pelayanan kesehatan yang diterimanya 3. Oleh karena itu dapat dikatakan penuntutan ganti rugi ini, baik diakibatkan karena kesalahan atau kesengajaan dalam pelayanan kesehatan. Penuntutan ditujukan terhadap seseorang, tenaga kesehatan maupun kepada pihak penyelenggara kesehatan (Rumah Sakit).

Dalam Pasal 46 Undang Undang Nomor 44 Tahun 2009 tentang Rumah Sakit menyebutkan bahwa penuntutan kerugian hanya ditujukan kepada pihak Rumah Sakit, yang diakibatkan secara khusus karena kelalaian tenaga kesehatan di Rumah Sakit. Hal ini dapat ditafsirkan bahwa kerugian yang diakibatkan karena kesengajaan tenaga kesehatan di Rumah Sakit, maka tidak dapat dilakukan penuntutan terhadap Rumah Sakit, karena disebabkan kesalahan yang disengaja tenaga kesehatan di Rumah Sakit.

Fenomena empiris serta pemaparan yuridis tentang dinamika sengketa medis dalam kaitannya dengan keberadaan Rumah Sakit Jiwa, semakin rumit tatkala perlu dilakukan pertanggungjawaban hukum atas sengketa yang ada. Hal ini harus diidentifikasi lebih teliti dan mendalam siapa subyek hukumnya, ${ }^{4}$ apa obyek hukumnya dan lain sebagainya, termasuk kedudukan hukum dari rumah sakit secara kelembagaan sebagai penyedia layanan kesehatan dengan tenaga kesehatan yang bersangkutan dan bagaimana hubungan hukumnya dengan penyedia layanan dalam hal ini Rumah Sakit.

Berdasarkan uraian tersebut diatas, penelitian ini mengkaji permasalahan tentang kedudukan hukum Rumah Sakit Jiwa dalam rangka melaksanakan fungsi pelayanan kesehatan jiwa dan tanggung jawab Rumah Sakit Jiwa dan petugas jaga atas pasien dengan gangguan jiwa yang melarikan diri dari ruang rawat inap. Secara teoritis penelitian ini diharapkan dapat memberikan sumbangan ilmu pengetahuan hukum khususnya di bidang kesehatan dengan melakukan pengkajian yang mendalam terhadap peraturan perundang-undangan yang berlaku saat ini, yang secara khusus menyangkut bidang kesehatan di rumah sakit. Secara praktis, hasil penelitian yang berfokus pada kebijakan kesehatan khususnya dalam penyelenggaraan rumah sakit khusus yang dalam kegiatannya berhubungan dengan tanggung jawab secara institusi. Sebagai pemberi jasa

\footnotetext{
${ }^{3}$ Lihat pasal 29 dan pasal 58 Undang Undang No. 36 tahun 2009 tentang Kesehatan
}

${ }^{4}$ Aspan, A., Arifin, A Ilyas., Yunus, A. (2019). "Perizinan Pengelolaan Wilayah Pesisir sebagai Kewenangan yang Diderivasi dari Hak Menguasai Negara", Al-Azhar Islamic Law Review 1 (1), 9-25. 
pelayanan kesehatan, sehingga diharapkan dapat menghasilkan suatu kepastian hukum pelayanan kesehatan di Rumah Sakit Jiwa yang efektif dan berkeadilan.

\section{Metode Penelitian}

Penelitian ini merupakan penelitian yuridis normatif (doctrinal legal re-search), dengan menggunakan studi kepustakaan sebagai bahan sekunder dan menggunakan metode berfikir secara deduktif yakni menarik kesimpulan berdasarkan dari dalil-dalil yang umum yang kemudian menarik pada perundang-undangan (statute approach) yang berhubungan dengan aturan-aturan mengenai hubungan rumah sakit, tenaga kesehatan, pasien, dan tanggung jawab dalam hal terjadi kelalaian dalam pelayanan kesehatan di Rumah Sakit Jiwa serta syarat-syarat kelalaian tenaga kesehatan dalam memberikan pelayanan kesehatan di rumah sakit. Disamping itu juga menggunakan pendekatan konseptual (conceptual approach) yaitu mempelajari pandangan-pandangan dan doktrin-doktrin di dalam ilmu hukum, yang mana peneliti akan menemukan ide-ide yang melahirkan pengertian-pengertian hukum, konsep-konsep hukum, dan asas-asas hukum yang relevan dengan penelitan yang dilakukan. Penelitian hukum normatif memerlukan data sekunder untuk mendukung analisis penelitian. Data sekunder adalah data yang bersumber dari peraturan perundang-undangan yang berlaku atau terdiri dari bahan hukum, baik primer, sekunder maupun bahan hukum tersier yang dikumpulkan melalui studi kepustakaan. Metode analisis data yang digunakan dalam penelitian ini adalah metode kualitatif normatif.

\section{Landasan Teoretis}

\subsection{Subyek Hukum}

Subyek Hukum adalah setiap pendukung hak dan kewajiban atau segala sesuatu yang dapat mempunyai hak dan kewajiban menurut hukum ${ }^{5}$. Subyek hukum juga diartikan sebagai manusia yang berkepribadian hukum dan segala sesuatu yang berdasarkan tuntutan kebutuhan masyarakat demikian itu oleh hukum diakui sebagai pendukung hak dan kewajiban ${ }^{6}$. Menurut KUHPerdata subyek hukum terdiri dari 2(dua), yakni manusia perorangan (natuurlijk persoon) dan badan hukum (Rechts persoon). Kedudukan manusia sebagai subyek hukum dalam melakukan perbuatan hukum haruslah mempunyai

${ }^{5}$ http://repository.unimal.ac.id,diakses tanggal 4 april 2018 pkl. 20.07 WIB

${ }^{6}$ Subekti, 2003, Pokok-pokok Hukum Perdata atau Subyektif, Cetakan 31, Intermasa Jakarta, hal.20. 
kapasitas hukum antara lain dewasa dan tidak dalam pengampuan atau dibawah perwalian. Badan hukum sebagai subyek hukum mempunyai hak dan kewajiban yang mempunyai peran untuk dapat melakukan tindakan hukum seperti membuat keputusan, bertindak didalam dan diluar pengadilan.

\subsection{Tanggung Jawab}

Tanggung jawab adalah suatu akibat atas konsekuensi kebebasan seorang tentang perbuatannya yang berkaitan dengan etika atau moral dalam melakukan suatu perbuatan ${ }^{7}$. Pertanggungjawaban dalam hukum dibagi menjadi dua yaitu pertanggungjawaban hukum pidana dan perdata. Pertanggungjawaban hendaknya mempunyai dasar, yaitu hal yang menyebabkan timbulnya hak hukum bagi seorang untuk menuntut orang lain sekaligus berupa hal yang melahirkan kewajiban hukum orang lain untuk memberi pertanggungjawabannya ${ }^{8}$.

\subsection{Orang Dengan Gangguan Jiwa}

Gangguan jiwa merupakan perubahan sikap dan perilaku seseorang, dimana orang yang terkena gangguan jiwa biasanya tidak menyadari bahwa tingkah lakunya menyimpang, tidak dapat mengendalikan diri dan bilamana pengendalian diri yang kurang tersebut sangat menyolok maka seseorang dapat dikatakan mengalami gangguan jiwa. Orang dengan Gangguan Jiwa yang selanjutnya disebut dengan ODGJ berbeda dengan Orang dengan Masalah Kejiwaan yang selanjutnya disebut ODMK. Lantas "Siapa yang bisa disebut ODMK?" jawaban sederhananya adalah setiap orang yang memiliki kerentanan untuk menjadi ODGJ dan siapa juga yang bisa disebut sebagai ODGJ?" jawabannya adalah setiap orang yang sudah mendapatkan diagnosis gangguan kejiwaan dari psikolog atau psikiater.

ODGJ dan ODMK adalah sama-sama lahir dari undang-undang, yaitu UndangUndang Nomor 18 Tahun 2014 tentang Kesehatan Jiwa yang dalam Pasal 1 disebutkan bahwa Orang dengan Masalah Kejiwaan adalah: “...orang yang mempunyai masalah fisik, mental, sosial, pertumbuhan dan perkembangan, dan/atau kualitas hidup sehingga memiliki risiko mengalami gangguan jiwa."Sementara itu, dalam pasal yang sama, Orang dengan Gangguan Jiwa adalah : “...orang yang mengalami gangguan dalam pikiran,

\footnotetext{
${ }^{7}$ Soekidjo Notoatmojo, 2101, Etika dan Hukum Kesehatan, Rineka Cipta, Jakarta.

${ }^{8}$ Titik Triwulan dan Shinta Febrian, 2010, Perlindungan Hukum bagi Pasien, Prestasi Pustaka, Jakarta.
} 
perilaku, dan perasaan yang termanifestasi dalam bentuk sekumpulan gejala dan/atau perubahan perilaku yang bermakna, serta dapat menimbulkan penderitaan dan hambatan dalam menjalankan fungsi orang sebagai manusia."

\subsection{Melarikan Diri}

Rumah Sakit Jiwa (RSJ) adalah tempat dimana penderita gangguan jiwa dirawat dengan khusus, baik itu rawat jalan maupun rawat inap. Bagi pasien gangguan jiwa yang sudah relatif lama di rawat tidak tertutup kemungkinan juga merasa jenuh sehingga ingin pulang. Karena masih perlu perawatan, sehingga oleh dokter belum mengijinkan pasien untuk pulang, yang dari waktu ke waktu oleh pasien dirasa sangat lama dan masih juga belum diijinkan pulang, bisa jadi pasien pulang dengan tanpa ijin dari petugas atau yang biasa disebut pasien melarikan diri dari ruang rawat inap rumah sakit. Kata melarikan menurut kamus besar bahasa Indonesia adalah menyelamatkan. Terkait dengan pasien jiwa yang sedah dirawat di rumah sakit, pasien melarikan diri adalah pasien yang keluar/pulang dari rumah sakit sebelum dokter perawat profesi lain mengijinkan pulang dan tidak ada surat ijin pulang dari rumah sakit ${ }^{9}$.

\section{Konsep Pertanggungjawaban Hukum Rumah Sakit}

Tanggung jawab publik rumah sakit sebagai penyelenggara pelayanan publik diatur dalam ketentuan Pasal 15 Undang-Undang Nomor 25 tahun 2009, tentang pelayanan publik yaitu mengatur tentang tujuan pelaksanaan pelayanan publik. Selain itu juga diatur dalam ketentuan Pasal 46 Undang-Undang Nomor 44 tahun 2009, tentang rumah sakit, yang menentukan bahwa rumah sakit bertanggung jawab secara hukum terhadap semua kerugian yang ditimbulkan atas kelalaian yang dilakukan oleh tenaga kesehatan di rumah sakit.

Secara garis besar subyek hukum yang dapat dikenai tanggung jawab di rumah sakit ditinjau dari sudut pelaku dapat dikelompokkan menjadi 3 golongan yaitu :

1. Tanggung jawab bidang perumahsakitan, penanggung jawab adalah Kepala Rumah sakit

2. Tanggung jawab bidang medik, penanggung jawab adalah masing-masing dokter.

3. Tanggung jawab bidang keperawatan, penanggung jawab adalah masing-masing perawat.

Kedudukan hukum rumah sakit jiwa dalam rangka melaksanakan fungsi pelayanan kesehatan jiwa, sebagai subyek hukum mempunyai hak dan kewajiban yang mempunyai

9 https://www.scribd.com/document/355418474/SPO-Melarikan-Diri, diaksers 14 November 2018, pk.13.23 
peran untuk dapat melakukan tindakan hukum seperti membuat keputusan, bertindak didalam dan diluar pengadilan. Dalam menjalankan fungsi pelayanan kesehatan kepada pasien rumah sakit melibatkan beberapa tenaga kesehatan. Dokter, pasien dan rumah sakit adalah tiga subjek hukum yang terkait dalam bidang pemeliharaan kesehatan. Ketiganya membentuk baik hubungan medik dan hubungan hukum. Hubungan medik dan hubungan hukum antara dokter, pasien dan rumah sakit merupakan hubungan yang obyeknya adalah pemeliharaan kesehatan pada umumnya dan pelayanan kesehatan pada khususnya.

Namun di dalam prakteknya tidak semudah dan sesederhana itu. Hal ini disebabkan karena pada kenyataannya ketiga kelompok tanggung jawab itu saling berkaitan dan saling berhubungan satu sama lain. Maka seringkali agak sulit diukur untuk memilah-milah dan memberikan batasan tanggung jawab secara tegas. Untuk mengetahui siapa yang diminta tanggung jawabnya, didalam suatu peristiwa harus dilihat secara kasuistik. Tidak dapat digeneralisir karena tergantung pada banyak faktor, seperti:

1. Situasi dan kondisi saat peristiwa itu terjadi;

2. Keadaan pasien (pre-existing condition);

3. Bukti-bukti yang bisa diajukan (medical record, saksi);

4. Apakah sudah dilakukan berdasarkan "standar profesi medik";

5. Apakah tidak terdapat kekeliruan dalam penilaian (error of judgement);

6. Apakah terjadi pendelegasian wewenang dan apakah pendelegasian tersebut dapat dibenarkan dalam kasus itu;

7. Apakah tidak ada unsur kelalaian (neglince) atau kemungkinan adanya unsur kesengajaan;

8. Jika ternyata ada unsur kelalaian : siapa yang lalai;

9. Apakah tidak ada kesalahan pada pasien itu sendiri karena;

a) Tidak menceritakan semua keadaan dirinya dengan kejujurannya;

b) Tidak menurut nasihat dokter dan melanggar larangan-larangan dokter/rumah sakit sehingga memperburuk keadaannya.

10. Tuntutan hukum yang diajukan, bisa berupa pidana, perdata, administratif.

Perlu juga dipikirkan seberapa jauh dampak hukum (resiko) yang dapat timbul terhadap manajemen rumah sakit. Siapa yang secara yuridis harus bertanggung jawab di rumah sakit apabila ada tuntutan hukum, dokter, perawat dan rumah sakit itu sendiri, berapa besar ganti kerugiannya.

Tanggung jawab itu sendiri apabila ditinjau dari perspektif rumah sakit maka tanggung jawab rumah sakit itu meliputi tiga hal yaitu; 
1. Tanggung jawab yang berkaitan dengan personalia;

2. Tanggung jawab yang menyangkut sarana dan peralatan;

3. Tanggung jawab yang menyangkut duty of care (kewajiban memberikan perawatan yang baik).

Untuk memperoleh kepastian tanggung jawab hukum terhadap rumah sakit dan petugas jaga atas pasien dengan gangguan jiwa yang melarikan diri dari ruang rawat inap, hal ini tergantung pada peraturan internal sebuah rumah sakit (hospital by laws), apakah peraturan tersebut sudah meliputi aturan-aturan berkaitan dengan pelayanan kesehatan, ketenagaan, administrasi dan manajemen. Secara umum rumah sakit sebagai suatu kesatuan organisasi atau badan hukum bertanggung jawab terhadap tindakan para karyawannya jika sampai ada yang mengakibatkan kerugian kepada orang lain. Hal ini termasuk apa yang ada dalam ilmu hukum dinamakan tanggung gugat vicarious liability atau tanggung gugat seorang majikan terhadap tindakan atau kesalahan karyawannya. Tanggung jawab rumah sakit terhadap personalia ini berdasarkan doktrin "Hubungan majikan-karyawan" (Vicarious Liability atau Respondent superior atau Master-servan Relationship, Let the Master Answer) yang terdapat di dalam kepustakaan hukum.

Hubungan majikan-karyawan berarti pertanggungjawaban seorang majikan terhadap suatu tindakan/non-tindakan (kelalaian) dari karyawannya yang sampai mengakibatkan kerugian pihak lain. Di Indonesia hal itu diatur dalam Kitab UndangUndang Hukum Perdata pasal 1367, 1366, 1365. Jika diantara majikan dan karyawan terdapat hubungan kerja, dalam arti jika karyawan menerima gaji dan melaksanakan instruksi atasannya (rumah sakit), maka hal ini tidak menimbulkan kesulitan. Menurut hukum perdata majikan dapat dimintai pertanggungjawabannya jika sampai menimbulkan kerugian atau cedera pada pasien yang diakibatkan oleh tindakan karyawannya.

Jadi kerugian yang ditimbulkan itu harus disebabkan karena perbuatan yang melawan hukum itu; antara lain kerugian-kerugian dan perbuatan itu harus ada hubungannya yang langsung; kerugian itu disebabkan karena kesalahan pembuat. Kesalahan adalah apabila pada pelaku ada kesenjangan atau kealpaan (kelalaian). Perbuatan melawan hukum tidak hanya terdiri atas satu perbuatan, tetapi juga dalam tidak berbuat sesuatu. Dalam KUHPerdata ditentukan pula bahwa setiap orang tidak saja bertanggungjawab terhadap kerugian yang disebabkan karena perbuatannya sendiri, tetapi 
juga terhadap kerugian yang ditimbulkan karena perbuatan orang-orang yang ditanggungnya, atau karena barang-barang yang berada dibawah pengawasannya.$^{10}$

Membandingkan bunyi Pasal 46 Undang-undang nomor 44 Tahun 2009 tentang Rumah sakit dengan Pasal 1367 KUHPerdata ayat (3), dapat diambil kesimpulan bahwa Pasal 46 Undang-undang nomor 44 tahun 2009 tentang Rumah sakit adalah derivate atau turunan dari Pasal 1367 KUHPerdata ayat (3) yang berlaku khusus untuk kalangan rumah sakit, atau Pasal 46 Undang-Undang Nomor 44 Tahun 2009 bersifat lex spesialis. Ketentuan Pasal diatas juga sejalan dengan ketentuan dari doktrin respondeatsuperior. Doktrin respondeat superior mengandung makna bahwa seorang majikan adalah orang yang berhak untuk memberikan instruksi dan mengontrol tindakan bawahannya, baik atas hasil yang dicapai maupun tentang cara yang digunakan.

\section{Penutup}

Kedudukan hukum Rumah Sakit Jiwa dalam rangka melaksanakan fungsi pelayanan kesehatan jiwa, sebagai subyek hukum mempunyai hak dan kewajiban yang mempunyai peran untuk dapat melakukan tindakan hukum seperti membuat keputusan, bertindak didalam dan diluar pengadilan. Dalam menjalankan fungsi pelayanan kesehatan kepada pasien rumah sakit melibatkan beberapa tenaga kesehatan. Dokter, pasien dan rumah sakit adalah tiga subjek hukum yang terkait dalam bidang pemeliharaan kesehatan. Ketiganya membentuk baik hubungan medik dan hubungan hukum. Hubungan medik dan hubungan hukum antara dokter, pasien dan rumah sakit merupakan hubungan yang obyeknya adalah pemeliharaan kesehatan pada umumnya dan pelayanan kesehatan pada khususnya.

Secara garis besar subyek hukum yang dapat dikenai tanggung jawab di rumah sakit ditinjau dari sudut pelakunya dapat dikelompokkan menjadi tiga golongan yaitu tanggung jawab bidang perumahsakitan, penanggung jawab adalah Kepala Rumah Sakit, tanggung jawab bidang medik, penanggung jawab adalah masing-masing dokter, tanggung jawab bidang keperawatan, penanggung jawab adalah masing-masing perawat. Rumah sakit bertanggung jawab atas tindakan pasien gangguan jiwa yang melarikan diri dari ruang rawat inap di rumah sakit, yang menyebabkan kerugian pada seseorang/pasien, dengan dasar:

\footnotetext{
${ }^{10}$ Hidajati, I. (2014). Kajian Yuridis Pengawasan Mutu Rumah Sakit Khusus Gigi Dan Mulut Pendidikan Melalui Akreditasi Rumah Sakit.Perspektif Hukum, 14(2), 94-109. doi:http://dx.doi.org/10.30649/phj.v14i2.35
} 
a. secara yuridis normatif hal ini merupakan penerapan ketentuan Pasal 1367 KUHPerdata, dan Pasal 46 UU Rumah Sakit, dan akreditasi pelayanan kesehatan;

b. secara yuridis doktrinal, rumah sakit bertanggung jawab atas tindakan pasien gangguan jiwa yang melarikan diri dari ruang rawat inap dengan adanya doktrin respondeat superior, dan rumah sakit bertanggung jawab terhadap kualitas perawatan (duty to care); dan

c. secara yuridis teoritis, rumah sakit sebagai korporasi, maka berlaku asas vicarious liability, hospital liability, corporate liability, sehingga rumah sakit dapat bertanggung gugat atas pasien gangguan jiwa yang melarikan diri dari ruang rawat inap yang berfungsi dalam kedudukan sebagai sub-ordinate (employee).

\section{Daftar Pustaka}

\section{Buku}

Adami Chazawi, 2007, Malpraktek Kedokteran, Bayumedia Publishing, Malang. Azrul Azwar, 2010, Pengantar Administrasi Kesehatan, Binarupa Aksara, Jakarta. Peter Mahmud Marzuki, 2008, Penelitian Hukum, Kencana Prenada Media, Jakarta. Soekidjo Notoatmojo, 2010, Etika dan Hukum Kesehatan, Rineka Cipta, Jakarta.

Subekti, 2003, Pokok-pokok Hukum Perdata atau Subjektif, Cetakan ke 31, Intermasa Jakarta.

Titik Triwulan dan Shinta Febrian, 2010, Perlindungan Hukum bagi Pasien, Prestasi Pustaka, Jakarta.

Jurnal

Aspan, A., Arifin, A Ilyas., Yunus, A., 2019, "Perizinan Pengelolaan Wilayah Pesisir sebagai Kewenangan yang Diderivasi dari Hak Menguasai Negara”, Al-Azhar Islamic Law Review, 1 (1), 9-25

Basuni, B, 2014, Tanggung Jawab Rumah Sakit Jiwa Terhadap Pegawai Yang Melakukan Kesalahan Tindakan Dalam Perawatan Pasien Gangguan Jiwa (Studi di Rumah Sakit Jiwa Menur Surabaya). Perspektif Hukum, 14(2), 110-123. doi:http://dx.doi.org/10.30649/phj.v14i2.36

Hidajati, I, 2014, Kajian Yuridis Pengawasan Mutu Rumah Sakit Khusus Gigi Dan Mulut Pendidikan Melalui Akreditasi Rumah Sakit.Perspektif Hukum, 14(2), 94-109. doi:http://dx.doi.org/10.30649/phj.v14i2.35

\section{Peraturan Perundang-undangan}

Keputusan Menteri Kesehatan Republik Indonesia Nomor 220/MENKES/SK/III/2002 tentang Pedoman Umum Tim Pembina, Tim Pengarah, Tim Pelaksana Kesehatan Jiwa Masyarakat.

Keputusan Menteri Kesehatan Republik Indonesia Nomor 406/Menkes/SK/VI/2009 tentang Pedoman Pelayanan Kesehatan Jiwa Komunitas.

Peraturan Menteri Kesehatan Republik Indonesia Nomor 340/MENKES/PER/III/2010 tentang Klasifikasi Rumah Sakit.

Peraturan Menteri Kesehatan Republik Indonesia Nomor 43 Tahun 2016 tentang Standar Pelayanan Minimal Bidang Kesehatan.

Peraturan Menteri Kesehatan Republik Indonesia Nomor 56 Tahun 2014 tentang Klasifikasi dan Perizinan Rumah Sakit. 